\title{
As Forças Armadas e a reflexão de Raymundo Faoro sobre a abertura política, $1984^{*}$
}

\author{
Maria José de Rezende \\ Universidade Estadual de Londrina
}

\section{Resumo}

A finalidade deste estudo é analisar os artigos de Raymundo Faoro, produzidos no último ano de vigência da ditadura militar no Brasil, que versavam sobre a democratização do país num ambiente político marcado por questões militares que enredavam a transição em processos que circunscreviam a abertura a uma forma de liberalização que não dava indicações de superação dos autoritarismos impregnados nas práticas sociais e políticas. Os textos de Faoro foram tomados como documentos capazes de revelar os principais movimentos dos agentes que tentavam intervir no curso dos acontecimentos desencadeados a partir de 1973 quando se iniciou o período de distensão.

Palavras-chaves: Democratização; Forças Armadas; abertura; distensão.

\begin{abstract}
The purpose of this study is to analyze Raymundo Faoro"s articles, written in the last year of the topicality of the military dictatorship in Brazil, which dealt with the democratization of the country in a political environment determined by military issues that involved transition in the processes that circumscribed the opening to a form of liberalization that did not show signs of overcoming authoritarianisms that pervaded the social and political practices. Faoro"s texts were considered as documents capable of revealing the main movements of agents that tried to intervene in the course of happenings that started in 1973, when the détente period began.
\end{abstract}

Keywords: Democratization; Armed Forces; political opening; détente.

\footnotetext{
- The Armed Forces and the Raymundo Faoros reflection on some difficulties of the political opening, 1984

1 Endereço para correspondências: Rua Pio XII, 335, ap. 1104, Londrina, PR, 86020-9.14 (wld@londrina.net).
} 


\section{Introdução}

$\mathrm{N}$

as décadas de 1970 e 1980 Raymundo Faoro (1925-2003) produziu, semanalmente, textos analisando a vida política nacional em meio ao processo de transição iniciado em 1973. Ele deixou documentado, através de um volume extenso de artigos, as ações e os movimentos dos diversos grupos sociais durante o processo de liberalização ${ }^{2}$. O jurista Raymundo Faoro, em 1958, publicou a obra Os donos do poder ${ }^{3}$ (1989) que tem grande relevância para o pensamento social e político brasileiro. "Ele esteve envolvido, no decorrer de sua vida, tanto em grandes polêmicas intelectuais e políticas quanto em acontecimentos que marcaram a vida nacional, como, por exemplo, o processo de transição que se inicia a partir de 1973 dentro da ditadura militar(1964-1985)" (Rezende, 2008a). Sua atuação mais relevante ocorreu no final da década de 1970 e início da de 1980.

Como presidente da Ordem dos Advogados do Brasil (1977-1979), Faoro participou, juntamente com outros membros da sociedade civil organizada, das ações políticas que visavam abrir caminho para o desfecho final do regime autoritário vigente no país desde 1964. Entre as suas incumbências à frente da $\mathrm{OAB}$ estava a de lutar pelo fim dos Atos Institucionais e pelo restabelecimento do habeas corpus. Visando tais objetivos, na condição de presidente da OAB, ele foi um dos representantes da sociedade civil no chamado "diálogo" que o Ministro da Justiça do governo Geisel, Petrônio Portella, passou a conduzir a partir de 1977. A denominada "política de distensão" que toma forma na segunda metade da década de 1970, a qual desaguou posteriormente na chamada "abertura política" (19791985), gerou um forte enfrentamento entre as forças conservadoras e as forças progressistas.

\footnotetext{
${ }^{2}$ As análises de diversos outros artigos de Faoro acerca da conjuntura política brasileira foram feitas em: (Rezende, 2006; 2006a ; 2006b; 2008b; 2009).

${ }^{3}$ Em 1975, a obra Os donos do poder teve uma segunda edição publicada. Nesta última, Raymundo Faoro redimensionou o livro ao incorporar novos conteúdos. A obra passou de 271 páginas para 766.
} 
Na condição de representante dessas últimas, Raymundo Faoro atuou [...] buscando sedimentar alguns caminhos por onde pudesse fluir uma sociedade democrática capaz de suplantar definitivamente $o$ autoritarismo arraigado na política e no Estado brasileiro (Rezende, 2006, p.38).

Não é possível, no âmbito de um único artigo, dar conta das várias discussões que ele trouxe à tona nesses materiais que eram publicados em revistas de circulação nacional como Isto É, Istoé/senhor, Senhor, etc. Por isso, neste artigo, especificamente, serão analisados os seus textos que versavam, em 1984, sobre as dificuldades de solucionar, naquele momento, os impasses postos pela questão militar que acabava tendo um papel prioritário no interior do processo de liberalização cuidadosamente manejado pelos governos militares.

As questões militares não eram as únicas a ter papéis relevantes no âmbito da transição, mas elas tinham sido, desde as atuações do presidente Ernesto $\mathrm{Geisel}^{4}$ (1907-1996), cuidadosamente pensadas e dirigidas naquele contexto de transição. Segundo Faoro, muitas medidas eram tomadas com o objetivo de resolver, em primeiro lugar, os impasses no interior das Forças Armadas que emergiram da distensão. Muitos eram os embates no interior do estamento militar que comandava a abertura. Eram diversos também os descontentamentos e confrontos que surgiram entre os segmentos militares que discordavam dos passos postos em marcha desde meados da década de 1970 .

Verificava-se nas manifestações públicas daqueles militares que compunham o grupo de poder que o processo de abertura assentava-se em inúmeras precauções, as quais se dirigiam também aos militares descontentes com a liberalização em curso. As contestações destemperadas - fossem elas de civis, fossem elas de militares - não eram toleradas pelo regime. Este último dava sinais claros de que estava empenhado em levar a proposta de descompressão, controlada pelo estamento militar que comandou a distensão, até os últimos dias ${ }^{5}$.

${ }^{4}$ O General Ernesto Geisel foi presidente do país entre 1973 e 1979.

${ }^{5}$ Faoro, no início da década de 1980, produziu muitos artigos sobre isto. Entre eles, ver: A cidade convulsionada (1981), A guerra dos Orixás (1981), O nordeste em questão: acertando as contas com a velha hegemonia (1981), O chefe e a sombra (1981), Nós, os suspeitos (1981), A insegurança como tutela (1981), Os resíduos da transição (1981), Só o futuro o dirá (1981), Quem acredita na democracia (1981). 


\section{HUMANAS}

Além de alguns artigos publicados por Faoro no ano de 1984 acerca da questão militar (Faoro, 05 set.1984; Faoro, 26 set.1984; Faoro, 03 out.1984), este artigo analisará também um documento produzido por Faoro em outubro de 1984 cujo título é Democratização e Forças Armadas (Faoro, 03 out.1984), no qual ele situava as dificuldades da liberalização em curso no fato de que, desde a proclamação da República, nunca vigorou, de fato, no país, qualquer soberania popular. Daí, o entendimento das Forças Armadas de que elas sustentariam e/ou garantiriam as Cartas Constitucionais e/ou os poderes constituídos. A democratização do país tinha, pela frente, a árdua tarefa de superar um padrão de domínio fundado, por um lado, na exclusão da maioria e, por outro, no pressuposto de que as Forças Armadas são as garantidoras ora dos poderes constitucionais como estabelecia a Carta de 1946 ora dos poderes constituídos como advogava a Carta de $1967^{6}$.

As Assembléias Constituintes de 1891, 1934 e 1946 inseriram na Constituição brasileira duas cláusulas particularmente fundamentais para o modelo civil-militar. Uma destas afirmava que os militares deveriam obedecer ao presidente, "dentro dos limites da lei". A segunda determinava que os militares constituem uma instituição nacional permanente, responsável pela tarefa específica de manutenção da lei e da ordem interna do país, assim como da garantia do funcionamento normal dos três poderes constitucionais. [...] A frase "dentro dos limites da lei" apresenta o perigo de legitimar a obediência discricionária militar e, neste sentido, cria condições que permitem que os militares assumam um papel deliberativo (Stepan, 1988, p.544).

\footnotetext{
${ }^{6}$ Havia uma gama de discussões no período da distensão (1973-1979) e da abertura (1979-1985) sobre as Forças Armadas e a vida política brasileira. Entre elas, ver: (Oliveira, 1980; Coelho, 1976; Stepan, $1971 ; 1986$ )
} 


\section{1 - As Forças Armadas e a função de sustentar a Constituição: alguns ele- mentos para entender os percalços da transição política no ano de 1984}

Raymundo Faoro demonstrou em vários escritos (Faoro, 1989; 1981; $1994 ; 1988$ ) que o papel preponderante assumido pelas Forças Armadas no país, após 1889 , foi resultado de um longo processo histórico. A proclamação da República teria sido o momento em que se sedimentou uma convicção: a de que as Forças Armadas tinham a função de sustentar a Constituição. Neste caso, elas foram alçadas à condição de "relevante fator de poder" (Faoro, 23 dez. 1998, p.22).

O golpe militar, expresso numa parada legitimou-se, com oportunismo, na mudança da forma de Estado. [...] A interferência militar, situada entre o imperador sem herdeiros políticos e o federalismo não amadurecido, desviou a direção dos acontecimentos, sufocou a revolução em marcha. O odiado Poder Moderador, destruído o Senado vitalício e o Conselho de Estado, encarnar-se-á, sem quebra da continuidade, em Deodoro e Floriano (Faoro, 1989,p.535).

No documento Democratização e Forças Armadas, Faoro mostra como a fixação, desde a instauração da República, de um papel extremamente relevante das Forças Armadas na defesa da Carta Magna, de 1891, trouxe conseqüências políticas ímpares para a nação. $O$ pressuposto de que as Forças Armadas, não o cidadão, é que estariam incumbidas de proteger a Constituição, teria representado um desvio significativo de rota no curso das mudanças políticas advindas da República. Isto porque o papel das Forças Armadas assumiu uma feição de extrema relevância ao serem incumbidas de defender as instituições constitucionais.

As Forças Armadas entram na Magna Carta com relevo desconhecido na lei fundamental do Império, que acentua o dever da obediência dos soldados (Artigo 147). Em 1831, o lugar das Forças Armadas situa-se nas "disposições preliminares", do título da Organização Nacional, 
no capitulo que traça as linhas fundamentais do regime e fixa as bases do exercício da soberania nacional. Esse deslocamento não é mero acaso e tem significação política, que se irradia a todo o texto constitucional (Faoro, 03 out.1984, p.2).

Raymundo Faoro pretendia demonstrar que uma das conseqüências mais nefastas deste processo de atribuir às Forças Armadas tamanha relevância política foi a asfixia do princípio de soberania popular, no qual é o cidadão e não o soldado o responsável pela defesa dos poderes constitucionais. É, então, aquele primeiro e não este último que tem de se armar politicamente de recursos para garantir a prevalência da Carta Constitucional.

O papel relevante que assume o soldado na condição de guardião dos poderes constitucionais abre todas as portas para o golpe de 03 de novembro de 1891, no qual o Marechal Deodoro da Fonseca ${ }^{7}$ dissolve o congresso e dá "ao Exército e à Armada, título de "depositários da vontade nacional". Ao ferir a Constituição [promulgada em 24 de fevereiro de 1891], invoca o marechal a fidelidade "à minha missão de soldado e de brasileiro", renovando o compromisso de assegurar às Forças Armadas "o seu elevado papel de "principais mantenedores da ordem e das instituições"' (Faoro, 03 out.1984, p.2).

Acontecimentos como esses, ao longo do século XX, que exorbitaram o papel das Forças Armadas como guardiãs da ordem e das instituições, possibilitaram não só golpes como o de 1937 e o de 1964, mas também emperramentos de grande monta no que diz respeito à constituição de um Estado democrático. Faoro mostrava que, historicamente, foram sendo formadas as condições para que as Forças Armadas, após 1964, se declarassem a guardiã dos poderes constituídos, o que se expressou na fixação das bases ditatoriais do regime que passou, então, a vigorar.

Os militares brasileiros adquiriram várias [prerrogativas] quando derrubaram o poder imperial em 1889; aumentaram-nas durante a ditadura de Vargas, especialmente durante o Estado Novo de 1937-1945. E mesmo após a redação da Constituição de 1946, várias destas prerrogativas foram mantidas pelos militares.

\footnotetext{
7 "Em 1891, o marechal Deodoro dissolve o Congresso. Vinte dias depois, desamparado de apoio em terra, e diante de uma revolta da Marinha, assume o vice-presidente Floriano Peixoto" (Faoro, 03 out.1984, p.3).
} 
Um sistema partidário frágil, que vem coexistindo com uma desigualdade social extremada ao longo da história brasileira, conduziu os redatores das constituições brasileiras, desde a fundação da República em 1889, a outorgarem aos militares um papel fundamental na manutenção da ordem interna. Por estes motivos, durante o período de governo civil (1946-1964), os militares puderam desfrutar de altas prerrogativas constitucionais, a coordenação do setor de defesa, seu papel nos ministérios e seu controle sobre os civis envolvidos em políticas de defesa. Também, neste período os militares continuaram a deter prerrogativas pelo menos moderadas [...]. Durante o período mais intenso de governo militar repressivo, as prerrogativas foram altas [...]. Durante o governo [Ernesto] Geisel, as prerrogativas militares relacionadas com o Executivo Federal e as prerrogativas da corporação foram reduzidas de altas para moderadas ${ }^{8}$ (Stepan, 1988, p.535).

A preponderância que vai assumindo as Forças Armadas como protetoras do poder constituído trouxe conseqüência não só para o processamento da vida política nacional no pós-64, mas também no decorrer da transição que se iniciou em 1973. Não era por acaso que havia uma supremacia da questão militar sobre as outras questões que foram desencadeadas pela distensão.

A prevalência da questão militar somente poderia ser compreendida se houvesse uma retrospectiva histórica sobre o modo como as Forças Armadas se constituíram relevante fator de poder que perdurou durante toda a República. Todavia, a partir de 1964 esta condição de relevante fator de poder foi se metamorfoseando em algo distinto que assumiu sua real feição com a implementação do Ato Institucional n.05 que escancarava que as Forças Armadas não seriam somente um fator de poder, mas sim as detentoras, por excelência, do poder.

\footnotetext{
8 "As prerrogativas militares constituem poder? A resposta é afirmativa quando elas permitem que seus detentores transformem questões latentes na agenda política em não-questões; quando seu exercício impõe limites para o conflito no sistema político; quando sua presença facilita o apelo de civis - com interesses a serem protegidos - para que as prerrogativas sejam de fato exercidas apoiando, portanto, o papel dos militares como atores poderosos no sistema político; e finalmente quando a defesa vigorosa das prerrogativas impede a implementação de outras iniciativas políticas importantes em curso" (Stepan, 1988, p.538).
} 
Nos governos Floriano [Peixoto] e Hermes [da Fonseca] tentaram, depois de investidos na chefia do governo, a tomada do poder, pela via militar, frustrada pela força das milícias estaduais, sobretudo de São Paulo e, em certos momentos, de Minas Gerais. Para bem interpretar o fato, basta ler, durante Floriano, a resistência de Campos Sales e Rodrigues Alves, entre outros, para que São Paulo se armasse, como condição de retirar os militares da cena, da qual saíram, humilhados, logo a seguir, pelos sucessos dos sertres da Bahia, como epicamente registron Euclydes da Cunha. No governo Hermes, criou-se, para embargar os passos do militarismo, o pacto do café-com-leite. Igualmente, o tenentismo, marcado de veleidades militaristas, que iriam sanear o País da corrupção dos paisanos, apesar de seus feitos intrépidos, também fracassou. Em 1930, supunha-se que as Forças Armadas tivessem sofrido um golpe mortal, vencidas pelas milícias estaduais do Rio Grande do Sul e de Minas Gerais. Mais uma vez, a expectativa delirou de suas possibilidades reais. Vargas, para consolidar seu poder, limitado pelos Estados, procurou novos sustentáculos. Um tradicional, tradicional, o Exército, reconstruído sob o comando de Góes Monteiro; outro, inédito, baseado na mobilização não participatória do povo. Plantaram-se, com esses componentes, as bases do intervencionismo, que, em primeiro tempo, o sustentou numa ditadura, $\mathrm{e}$, em outra hora, o alijou do poder. Daí por diante, os golpes eram um recurso político de uma ou outra facção política (Faoro, 23 dez.1998, p.22).

No artigo Uma ilusão trágica, de dezembro de 1998, escrito com a finalidade de debater os efeitos do Ato Institucional n.05 que completava 30 anos naquele momento, Raymundo Faoro continuava discutindo, tal como havia feito em 1984, a necessidade de dar continuidade ao processo de desmontagem do poder militar que persistiria mesmo depois da ditadura. 
Tal processo de desmontagem não era fácil, já que desde o Ato Institucional $\mathrm{n}^{0} 5$ teria ficado claro que os militares não eram simplesmente os guardiões dos interesses das classes dominantes e dirigentes ${ }^{9}$. A ilusão de que as forças armadas seriam, após 1964, somente guardadoras dos interesses preponderantes se desfez como espuma ao vento com a edição do ato acima mencionado. Por isso, Faoro considerava este último como um dos capítulos mais elucidativo da história política brasileira, já que ele "inaugurou o militarismo, de maneira aberta e sem biombos" (Faoro, 23 dez.1998, p.22).

No imediato pós-1964, tinha-se a ilusão de que os militares seriam somente protetores de alguns interesses. Ou seja, de que eles continuariam sendo um fator relevante de poder, mas não se converteriam no elemento preponderante de poder. $\mathrm{O}$ equívoco desta idéia foi desfeito em dezembro de 1968 quando passou a vigorar o Ato Institucional $n^{\circ} 5$. Todavia, era necessário notar que desde os Atos Institucionais n.2 e n.3 já estava evidenciada a não-transitoriedade do arbítrio em apenas alguns meses ou anos. Alguns setores dominantes ou alguns políticos poderiam ter tido em mente, no período imediatamente após o golpe, que a intervenção militar era passageira. No entanto, após o segundo e o terceiro Ato Institucional não havia mais razão alguma para se acreditar nisso, pois esses dois atos $\left(0 n^{\circ} 2\right.$ e o $n^{\circ}$ 3) já deixavam evidente que os políticos estariam:

[...] agora dependentes dos quartéis. Mesmo assim, pensou-se que uma Constituição autoritária, escoltada por uma draconiana Lei de Segurança Nacional, conteria a sede ditatorial do próximo general-presidente. O Ato Institucional $n^{\circ} 5$ desaçaimou o militarismo, liberto do cabresto que inermemente fora posto nas Forças Armadas. [...] O Ato Institucional $\mathrm{n}^{\circ} 5$ consagra o fim de uma ilusão, comum no período intervencionista, a de usar os militares atreando-os a fins políticos, mantendo-os fora do mando real. Os militares já se haviam libertado da classe dirigente,

\footnotetext{
${ }^{9}$ Os principais dispositivos do Ato Institucional $\mathrm{n}^{\circ} 5$ afirmavam que o presidente da República poderia: decretar o recesso do Congresso Nacional, Assembléias Legislativas e Câmaras de Vereadores; decretar a intervenção nos Estados e municípios; suspender os direitos políticos de quaisquer cidadãos. Foram suspensas as garantias constitucionais e de habeas-corpus. Excluia-se, ainda, qualquer apreciação judicial acerca dos atos praticados de acordo com o Ato Institucional n. ${ }^{\circ} 5$.
} 
que queria que as Forças Armadas, domesticadas por ela, ocupasse o poder apenas transitoriamente. Na verdade, o poder militar modelou seu simulacro de classe dirigente, que persistiu, em parte, mesmo depois de sair da cena (Faoro, 23 dez.1998, p.22).

A supremacia da questão militar sobre quaisquer outras questões, durante a transição estava encravada neste processo que transformou os militares de fator relevante de poder em fator preponderante do poder. Inúmeras dificuldades do processo de transição estavam ancoradas aí. A distensão e a abertura não tinham, dentro deste contexto, como caminhar no sentido da democratização, poderiam sim efetuar algumas liberalizações. Faoro estava convicto de que aquela primeira não seria alcançada porque a soberania popular havia sido completamente eliminada após 1964.

Se, ao longo da história do país, tinha sido subtraída a possibilidade dos diversos segmentos adentrarem a arena política, esta situação havia se agravado muito nos períodos ditatoriais. A inviabilidade da soberania popular teria sido cuidadosamente cultivada no decorrer da República brasileira. Bastava observar os acontecimentos no limiar do processo republicano. Ele afirmava:

Desenvolveu-se, no seio de um regime construído pelas armas, o predomínio destas, no dorso de uma escusa, constitucional, que prosperou na passiva e inerte cidadania. [Até mesmo Ruy Barbosa] - numa contorção que iria perturbar muitos políticos civis - refugiaria suas esperanças no Exército, para o qual num compromisso; os constituintes de [18]91 urdiram um abrigo na lei maior (Faoro, 03 out.1984, p.2).

A não-formação de uma soberania popular teria alimentado as dificuldades de constituição de uma cidadania substantiva. Os diversos grupos sociais passaram, desde 1964, a ser vistos, pelo estamento militar que estava à frente do poder, como devedores de obediência absoluta aos poderes constituídos. 
A repressão que recaiu sobre os setores da sociedade civil que tentavam questionar o processo em curso, era a prova mais contundente de que não seriam aceitas quaisquer tentativas de adentrar a arena política. A noção de obediência que passa a valer para militares e civis, durante a ditadura militar iniciada em 1964, exorbitava o pressuposto sustentador do golpe de que a segurança estava acima de qualquer outra coisa. "A Constituição de 1967 ampliou o Conselho de Segurança Nacional situando a segurança nacional como o dever básico e fundamental de toda "pessoa natural ou jurídica (Artigo 89)" (Faoro, 03 out. 1984, p.4).

A segurança estava, então, acima do desenvolvimento, das reivindicações sociais de toda e qualquer natureza e das ações políticas, fossem elas quais fossem ${ }^{10}$, etc. Celso Furtado fazia a seguinte afirmação:

Estávamos agora diante de um projeto "modernizador" que partia da idéia de que tanto a distribuição eqüitativa da renda como a convivência democrática somente são alcançadas nas fases superiores do desenvolvimento. Assim, havia antes que conhecer as dores do parto da "acumulação primitiva". Para essa gente o desenvolvimento é um processo de domesticação da sociedade, requer o exercício de um poder autoritário. Enfim, era a vitória da doutrina da modernização tutelada (FURTADO, 1997, p.56).

A insistência, feita pelos condutores do regime militar, de que todos, sem exceção, tinham de se submeter a uma dada ordem política e social, instaurada a partir de 1964, foi o suporte do regime militar durante toda a sua vigência. Toda e qualquer mobilização era enquadrada como crime contra a ordem política e social, isto já é mais do que o suficiente para suprimir toda possibilidade de intervenção, por parte das forças sociais que não compunham o bloco de poder da ditadura, no processo político em curso.

\footnotetext{
${ }^{10}$ Celso Furtado afirmava que, no pós-1964, ocorreu a paralisação da vida política no país (Furtado, 1992). E isto tem que ser analisado à luz das seguintes condições sociais: "(...) a atividade política amadureceu significativamente no período que vai desde o fim da ditadura de Vargas, em 1945, até o retorno dos militares ao poder, em 1964. Não é de estranhar que essa efervescência do acontecer político, ao incorporar segmentos da população até então adormecidos, haja assustado as forças conservadoras que controlavam o poder. Mas é inegável que, nesses dois decênios a que nos referimos, a participação do povo na construção institucional do Brasil marcou-o definitivamente" (FURTADO, 31 dez. 2002, p.3)
} 


\section{HUMANAs}

O pressuposto da obediência inconteste que predominou de forma absoluta no decorrer do regime pós-64 esteve sempre acompanhado de um procedimento: a necessidade de avisar, de alardear acerca das consequiências da não-obediência. Isto foi mantido até o último momento do regime.

Note-se que a Carta Constitucional de 1967 já nasceu sob a "escolta de uma ordem de segurança nacional, definida num decreto-lei, on. 314/67" (Faoro, 03 out.1984, p.5). Vale dizer que até mesmo a Carta Magna passava a estar ancorada numa Lei de Segurança Nacional que dava ao regime uma feição ditatorial que ia se recrudescendo no decorrer dos anos que se seguiam até atingir o seu ápice com a edição do Ato Institucional $\mathrm{n}^{\circ} 5$, em 1968. Faoro afirmava que era possível detectar vários golpes dentro do golpe-mestre desferido em março de 1964.

Em 17 de outubro de 1969, uma outorga, depois de declarar, no preâmbulo, que a Carta de 1967 "na sua maior parte, deve ser mantida", introduziu profundas modificações no funcionamento dos poderes, particularmente na estrutura do poder anômalo, ora sob estudo, que floresce na estufa das plantas raras. Ao Conselho de Segurança Nacional, órgão formalmente vinculado ao Poder Executivo, compete: Estabelecer os objetivos nacionais permanentes e as bases para a política nacional (Artigo 89). Um toque revela, num facho de intensa luz [...]. A letra do parágrafo único do Artigo 92 do Estatuto de 67 incorporou-se ao Artigo 91 da vigente Carta, com um acréscimo. Onde se dizia que as Forças Armadas destinam-se à defesa da Pátria e à garantia dos Poderes constituídos, da lei e da ordem, incluiu-se, logo após Forças Armadas, esta espada de fogo: "Essenciais à execução da política de segurança nacional". $O$ velho estado de sítio, que na versão de 67 só recebia o controle a posteriori do Congresso Nacional, num retrocesso a 37 - sempre 37 , modelo sagrado - alargou-se em 1978, 


\section{As forças armadas e a reflexão de Raymundo Faoro sobre a abertura política, 1984 \\ Maria José de Rezende}

num elenco de emergências cuja amostra a Nação viu atônita e escandalizada, em Brasília, por ocasião, da votação da emenda que restabeleceria as eleições diretas (Faoro, 03 out. 1984, p.5).

O período entre 1980 e 1984 foi repleto de acontecimentos que insistiam na necessidade de seguir à risca as decisões do estamento militar. $\mathrm{O}$ general João Batista de Oliveira Figueiredo ${ }^{11}$ (1918-1999) veio a público, algumas vezes, bradando que todos aqueles que desobedecessem as suas ordens expressas seriam trucidados. Ele sentenciava que não hesitaria em punir todos aqueles que se pusessem no caminho da abertura por ele conduzida. Em 1978, quando era ainda candidato à presidência, ele dizia "estar disposto a conter "quaisquer manifestações de radicalismo, da esquerda ou da direita"' (Figueiredo, 13 set.1978, p.21).

Raymundo Faoro afirma que essa insistência numa obediência cega, a qual estava muito presente na fala do estamento militar que comandava o regime entre 1964 e 1985, tinha de ser lida à luz da exigência de obediência absoluta que vigorava entre os militares. Quando os presidentes militares insistiam que não havia lugar, no interior daquela ordem política e social, para o questionamento, eles estavam reproduzindo a convicção de que os subordinados deveriam obedecer sempre. Não se deve esquecer que o estamento militar lutou incansavelmente para subordinar todos os segmentos sociais aos seus ditames. Isto não quer dizer que os setores preponderantes economicamente não agiram ativamente no processo de manutenção da ordem ditatorial em vigor. Estabelecia-se uma aliança civil-militar na qual o estamento militar dirigente exigia submissão, até mesmo, de seus aliados no processo político em curso ${ }^{12}$.

As Forças Armadas teriam sido vistas, em alguns momentos ao longo da República, por elas mesmas e por outros segmentos não só das elites, como detentoras da "função arbitral dos destinos da República. Aquelas primeiras estariam, portanto, em lugar da soberania nacional e popular" (Faoro, 03 out.1984, p.3). Talvez isso explique a junção de diversos segmentos (dominantes e médios) em favor da doutrina da segurança nacional.

\footnotetext{
"O Gal. João Batista de Oliveira Figueiredo governou o país entre 1979-1985.

${ }^{12}$ Isto ficou evidenciado em muitos momentos no decorrer do regime militar. Ver: (Rezende, 2001).
} 
Celso Furtado, no livro A fantasia organizada, afirmava que causava uma certa perplexidade a junção, a partir de 1964 , dos setores empresariais com os proponentes da doutrina de Segurança Nacional (Furtado, 1997a, p.284). Todavia, para Faoro isto não causava estranheza se fosse observado como ao longo da República as Forças Armadas foram vistas, pelas elites, como possuidoras de uma função tutelar dos destinos da nação, o que explicava não só a junção das elites ao projeto das Forças Armadas, mas também o apoio dos demais setores sociais ao golpe militar.

Todavia, Faoro afirmava que era necessário não supor que tudo se fazia em razão da consagrada servidão voluntária da sociedade como um todo. Não se devia supor também que a tutela se fazia porque ela estava constando nas Cartas Constitucionais. Tais suposições tornariam as explicações extremamente simplistas. Ele dizia que não era possivel supor que as fórmulas constitucionais de 1891, 1934, 1937, 1946 e 1967 eram idênticas.

Não eram idênticas porque em alguns momentos houve maior ou menor equilíbrio entre os poderes civis e militares. O que Faoro denominava de "transação consubstanciada nas fórmulas constitucionais de 1891, 1934, e 1946" (Faoro, 03 out.1984, p.4). Esta transação teria se rompido nas Cartas de 1937 e de 1967.

Na Constituição de 1967, [...], destinam-se as Forças Armadas a defender a Pátria e a "garantir os poderes constituídos" (Artigo 92, parágrafo 22). Permanece a cláusula "dentro da lei" (Artigo 92). Seria rematado absurdo - que, não obstante, tem sido sustentado - afirmar, diante da letra da lei maior, que nos dois regimes ditatoriais - 1937 e 1964 - as Forças Armadas entraram no caminho da disciplina e da hierarquia, alheias à direção política do País. A explicação é outra e bem clara. Não há necessidade de transação, quando os fatores que a compõem saem do nível de relativo equilíbrio. Agora, num caso e noutro, há o predomínio, a supremacia, o comando militar, dissimulado na primeira ocorrência, na figura de um ditador civil e, na segunda, aberto e visível na presença dos generais-presidentes (Faoro, 03 out. 1984, p.4). 
É em razão de tais constatações que Raymundo Faoro insistia que o regime militar tinha a sua frente um estamento militar que subordinava todos os demais segmentos sociais aos seus desígnios. É claro que o modo de submissão e de subordinação foi distinto em relação aos diversos grupos sociais. Como havia uma articulação entre o estamento dirigente e as classes dominantes, era visível que, neste caso especificamente, a relação de subordinação tinha características distintas daquela estabelecida sobre os demais segmentos sociais. A repressão se fazia presente entre os setores que não fizeram alianças com o estamento militar. Ou seja, todas e quaisquer contestações desses segmentos nãoaliados eram vistas como ameaças à ordem pública e social. Quando alguns grupos preponderantes protestavam contra alguma medida posta em andamento pela ditadura havia, no máximo, advertências e avisos sobre a não-aceitação de que fossem contestadas as decisões expressadas pelo núcleo no poder.

A articulação do estamento militar com os setores dirigentes era extremamente complexa, do ponto de vista político. Mesmo porque a subordinação esbarrava em inúmeros interesses incrustados dentro e fora do Estado. Por isso, às vezes, alguns setores economicamente dominantes tentavam reagir a algumas medidas postas pelo núcleo de poder da ditadura, mas eram alertados rapidamente pelos civis, os tecnoburocratas, que os militares não aceitariam afrontas de qualquer natureza ${ }^{13}$. Insistia-se, então, que havia sim o predomínio, a supremacia do estamento militar.

Faoro buscava demonstrar, no documento Democratização e Forças Armadas que, no período da distensão (1973-1979) e no da Abertura (19801985) essa supremacia do estamento militar estava na base das dificuldades de mudança política rumo à democratização. Os impasses oriundos de tais condições permitiam que os dirigentes acenassem para a liberalização e não para a democracia. Alfred Stepan afirmava

[...] várias vezes, no final dos anos 70 e no início dos anos 80 , os militares alteraram as regras do jogo da sociedade política [...]. Nesse período, a sociedade civil quase nunca veio em defesa da sociedade política. Os estrategistas do regime estavam compreensivelmente felizes com esse padrão de comportamento que sustentava mais a liberalização do que a democratização (Stepan, 1986, p.12).

${ }^{13}$ Sobre isto, ver: (Rezende, 1996; 2001). 


\section{HÜMANAS}

Aquestão militar principal era: como fazer a descompressão sem perder a supremacia diante de outras forças sociais dominantes que, em alguns casos, estavam sendo pressionados por alguns segmentos organizados da sociedade civil? Veja-se, por exemplo, o caso dos empresários pressionados pelas greves que ocorrem no final da década de 1970 e início da de 1980.

Observe-se que mesmo Faoro não discutindo detalhadamente, como fez Alfred Stepan em alguns textos $(1986 ; 1988)$ publicados após 1985, o papel que os militares teriam após a ditadura bem como as possibilidades ou não dos governos civis exercerem controles sobre eles, ele considerava que o processo de transição iniciado em 1973, assentado numa transação entre "círculos minoritários da sociedade civil e das Forças Armadas" (Faoro, 03 out.1984, p.4), dava muitas pistas sobre as dificuldades futuras de subtrair os poderes exorbitantes que estavam nas mãos do grupo de poder composto por civis e militares.

Dentro da transação, atuam unicamente círculos minoritários, nas Forças Armadas e na Sociedade civil, por imperativo do sistema. Seu produto são as conciliações de elites, que podem ou não buscar, a posteriori, o consentimento popular, meio exclusivo da legitimação. [...] As eleiçбes negaram legitimidade a 64. Para sair do imobilismo das questðes insolúveis, da resignação desesperada, resta a fisionomia desprezada na equação das transações, o apelo e o ordenamento da soberania popular, sem agentes ou tutores que a escravizem e a manipulem. $O$ arsenal que alimenta a mudança não está nos quartéis, mas na sociedade civil. Não será com o aliciamento da boa vontade dos generais e, na falta destes, dos coronéis, e, na falta destes, dos capitães, e, na falta destes, dos sargentos, que se encontrará o rumo da democracia (Faoro, 03 out.1984, p.4).

A ele parecia, em 1984, que uma das dificuldades da transição assentava-se, justamente, no fato de que o estamento militar que se encontrava no poder supunha que o debate político sobre o papel das Forças Armadas, 
no pós-ditadura, devia-se desenrolar somente nas casernas. Isso indicava que estava pressuposto que a sociedade civil não deveria ser o lócus por excelência de enfrentamento da seguinte questão que havia persistido durante toda a República: como a subtração do poder popular e da soberania estava assentada na crença, por parte de diversos segmentos sociais, de que as Forças Armadas possuíam uma função arbitral?

Caso persistisse essa fórmula autoritária composta pela crença, que esteve em vigor desde 1889, de que as Forças Armadas eram as guardiãs da sociedade, ter-se-ia uma liberalização que não se transmutaria em democracia de modo algum.

Um corolário se segue: o sistema político, para se afastar de seduções envolventes e escandalosas, não há de ser o de 91 , o de 34 e o de 46. O modelo de democracia há de ser outro, sem a falsa representação da República VeIha, a ambigüidade da Segunda República, e o elitismo de 46 , todos com vicioso lastro autoritário, encanecidos, no berço, pela herança estamental de um país que ainda não houve (Faoro, 03 out.1984, p.4).

A questão central posta nos últimos anos da ditadura era: qual o peso político que continuariam tendo os militares ${ }^{14}$ após $1985^{15}$ ? Como "desde meados dos anos 20, todos os chefes dos ramos das Forças Armadas sempre desfrutaram de pleno status ministerial"'(Stepan, 1988, p.536), era notória uma inquietude, por parte dos militares, acerca da possibilidade de que os governos civis viessem a questionar a manutenção dessa prerrogativa.

${ }^{14}$ Sobre isto, ver: (Zaverucha, 2000).

${ }^{15}$ Jorge Zaverucha faz uma reflexão sobre o modo como os militares conseguiram manter, nos anos que sucederam a ditadura,

[...] uma boa parte de seus enclaves autoritários dentro do aparelho de Estado [...]. A Constituição Federal de 1988, escrita por civis, manteve o papel constitucional das Forças Armadas como garantes do poder político. Elas são baluartes da lei e da ordem definidas por elas mesmas, não importando a opinião do presidente da República ou do Congresso Nacional. Portanto, cabe às Forças Armadas o poder soberano e constitucional de suspender o ordenamento jurídico do Brasil (Zaverucha, 26 nov.2004, p.3). 
E além desse status ministerial para os chefes das Forças Armadas, pairavam também dúvidas sobre os cargos adicionais que foram criados pelo regime em vigor após 1964. Tais cargos, o de chefe do Gabinete Militar, o chefe do SNI (Sistema Nacional de Informaçð̃es) e o de chefe do Estado-Maior das Forças Armadas - eram ocupados também por generais (Stepan, 1988).

Observe-se que muitas coisas estavam em jogo durante o processo de transição. Raymundo Faoro demonstrava que ao examinar a Constituição de 1967/1969 se verificava uma ramificação do poder das Forças Armadas no interior do aparelhamento estatal que ficava difícil desmontar nos anos subseqüentes. A matriz desse processo extensivo estava no modo como o regime militar passou a sustentar uma política repressiva para toda e qualquer ação contestatória vinda dos segmentos não preponderantes. Isto era feito em nome da segurança nacional e da defesa da ordem pública. Impedia-se, assim, a emergência de toda e qualquer ação política que contestasse o modo como o regime instrumentalizava o Estado em favor da sedimentação de procedimentos autoritários e concentracionistas de poder.

A própria constituição de 1967, promulgada em 24 de janeiro para que entrasse em vigor a 15 de março do mesmo ano, recebeu, entre as duas datas, a escolta da lei de Segurança Nacional (decreto-lei n.314, de 13 de março de 1967). A legalidade, com a paródia da legitimidade constitucional, colocou, ao lado de cada liberdade, a física, a de expressão, a de reunião, a de associação, uma sentinela vigilante, armada com o bacamarte e as algemas. Os cidadãos tudo poderiam fazer, contanto que nada fizesse para turbar o poder da posse mansa e arbitrária do poder. A definição vaga e fluida dos crimes, que a todos ameaçavam, condenava à insegurança geral, ao temor do processo criminal, julgado pela justiça militar (Faoro, 1981, p. 72-3).

Em 17 de dezembro de 1978 passava a vigorar uma nova Lei de Segurança Nacional, a n. 6.620/78 ${ }^{16}$. Permanecia intacta, no seu interior,

\footnotetext{
${ }^{16}$ A Lei n.6.620, de 17 de dezembro de 1978, pode ser encontrada em: http://www.planalto.gov.br/ ccivil_03/Leis/1970-1979/L6620.htm
} 
a idéia de que toda perturbação da ordem pública deveria ser duramente combatida. A segurança continuava a ser posta à frente da liberdade e do direito. Continuava a vigorar uma idéia de crime indefinido, impreciso, o que dava continuidade à Doutrina de Segurança Nacional que punha todos sob uma vaga suspeita, mas nem por isso menos ameaçadora (Faoro, 22 jan. 1981, p.13). "A definição vaga e fluida dos crimes, que a todos ameaçavam, condenava à insegurança geral, ao temor do processo criminal, julgado pela justiça militar"'(Faoro, 1981, p.72-3).

Era visível que, no seu conjunto, todos os procedimentos advindos de leis e decretos-leis, que enalteciam o poder dos militares, se constituíam em fatores que dificultavam a transição política. A truculência havia sedimentado um autoritarismo difícil de desmontar, o que tinha a ver, até mesmo, com os papéis que, durante a República foram atribuídos aos militares na solução das crises, "as cultivadas e as genuínas" (Faoro, 03 out.1984, p.5). As denominadas transações que haviam prevalecido, dizia Faoro, em 1891, $1934 \mathrm{e}$ 1946, não tinham sido possíveis em 1967 quando o estamento militar enfeixou em suas mãos poderes absolutamente ditatoriais.

Se os períodos de transação entre civis e militares haviam deixado máculas enormes no processamento da vida política nacional, imaginem-se as nódoas que deixariam o regime iniciado em 1964. “Em 1946, a visão alcançava o regime de 37 , não advertido quanto à profundidade do iceberg submerso" (Faoro, 03 out.1984, p.5). Por isso, não havia dúvida de que, no pós- 1985, a visão alcançaria, indubitavelmente, 1964 e todos os seus desdobramentos em 1967/1968 ${ }^{17} / 1969^{18}$. Recentemente, em entrevista à $\mathrm{Fo}$ lha de S. Paulo, Jorge Zaverucha, fez a seguinte observação ao sustentar a necessidade de que os códigos penais militares sejam readequados para que ocorram avanços rumo a uma democratização do Estado brasileiro:

O primeiro passo é mudar o Código Penal Militar. Não se explica que, numa "semidemocracia", se tenha um código de 1969, ápice do regime militar.

\footnotetext{
17 No ano de 1968 foi decretado o Ato Institucional $n^{\circ}$ 5, o qual "derruba o padrão político evolutivo plantado desde a independência pelos herdeiros do despotismo ilustrado pombalino. Este padrão pressupunha um espraiamento progressivo das liberdades reservadas à burocracia do Império e às oligarquias. Instituições embrionariamente democráticas iriam ampliando seu escopo, à medida que a população fosse "civilizada" pelas elites. Doravante, a regra não tinha mais validade. A "evolução civilizadora" foi rompida por elites que enveredavam pela barbárie" (Alencastro, 16 maio 1994, p.3).

18 A partir de $1967 / 1969$ o país passava a ter uma nova Carta Constitucional que suplantava a Carta de 1946.
} 
Nenhuma democracia, que mereça esse nome, segue o padrão brasileiro. O governo Fernando Henrique tentou criar uma comissão para fazer mudanças [no Código Penal Militar], mas ela foi logo abortada. Desde então não se toca mais no assunto. Os militares têm força política muito grande (Zaverucha, 22 mar. 2009, p.11).

\section{2 - Últimas consideraçōes sobre algumas dificuldades da transição e da democracia que eram perceptíveis em 1984}

Faoro insistia, em 1984, que, em parte, as dificuldades da transição se inscreviam no fato de que o poder militar ancorava-se "dentro da Constituição, em atividade prevista e demarcada" (Faoro, 03 out.1984, p.5). Desmantelar tais demarcações parecia imensamente dificil nos anos posteriores ao regime, já que elas teriam, no decorrer do regime militar, operado de modo a fixar as fronteiras de ação de todos os demais segmentos sociais. "Os partidos, as classes sociais, os sindicatos - toda sociedade civil - passaram a atuar em limites prefixados, que não poderiam transcender as fronteiras demarcadas, permamentemente ameaçados de retaliações coercitivas" (Faoro, 03 out.1984, p.5).

Tais práticas coercitivas se assentavam na vigência tanto da ideologia da segurança nacional quanto num sistema de idéias e valores difusos sobre a capacidade dos militares de imiscuírem-se nos assuntos políticos em geral para garantir a ordem pública. Essa ideologia se alastrou desde os primórdios da proclamação da República e foi insistentemente difundida pelos condutores do regime militar através de uma estratégia psicossocial, assim denominada pelos próprios condutores da ditadura. Somente os militares eram apontados como capazes de salvar o país de todos os males; basta ver sobre isso os argumentos dos formuladores da doutrina da Escola Superior de Guerra (ESG) naquele momento ${ }^{19}$.

No entanto, Raymundo Faoro considerava essencial que a análise se ativesse, com cuidado, aos procedimentos políticos que se tornaram possíveis em razão da Carta Constitucional em vigor. Tanto no âmbito dos procedimentos quanto no de uma teia cultural que sustentava o sistema político é

19 Sobre isto, ver: (Rezende, 2001, p. 29-43). 
que se teria de buscar entender os efeitos duradouros das práticas ditatoriais que vigorariam para além de sua vigência. E como seria possível desmontar a possibilidade de se ter, no futuro, ou seja, no período pós-regime militar, "a tutela estamental das Forças Armadas"?

Não será abolida a tutela estamental das Forças Armadas com o seu retraimento aos quartéis. Elas só permanecerão dentro da lei, se democrático for o regime, um regime que solva as reivindicações da sociedade, suas perplexidades e inquietudes, no confronto das urnas e da opinião pública. Não basta a conduta corajosa, que não receie a malquerença dos militares, nem corteje seus favores. Para que elas sejam dispensadas da função de "sustentar" (Constituição de 1891], "garantir" (Constituição de 34], [...] "defender" e "garantir" os poderes constitucionais [Constituição de 46] ou "garantir" e "defender" os poderes constituídos (Constituição de 67] é necessário que o povo não conte com ninguém acima dele nas disputas dos partidos, que só ele, por si mesmo e por seus legítimos representantes, nos Parlamentos e nos tribunais, delibere e atue (Faoro, 03 out. 1984, p.5).

\section{Referências bibliográficas}

ALENCASTRO, L. F. de. 1964: Por quem dobram os sinos? Folha de S.Paulo, São Paulo, 16 maio 1994. C.1, p.3

COELHO, E. C. Em busca da identidade: o Exército e a política na sociedade. Rio de Janeiro, Forense-Universitária, 1976.

FAORO, R. Os advérbios do senhor ministro. Senhor, São Paulo, n.181, p. 31, 05 set. 1984.

FAORO, R. Aguerra dos centros. Senhor, SãoPaulo, n.184, p.31,26 set. 1984.

FAORO, R. Negócio de ciganos. Senhor, São Paulo, n. 185, p. 31, 03 out 1984. 
FAORO, R. Democratização e Forças Armadas. Senhor, São Paulo, n. 185, 03 out.1984. Documento, p.1-5.

FAORO, R. Os donos do poder: formação do patronato político brasileiro, 8.ed. Rio de Janeiro: Globo, 1989.

FAORO, R. Assembléia constituinte: a legitimidade recuperada. São Paulo, Brasiliense, 1981.

FAORO, R. Existe um pensamento político brasileiro? São Paulo, Ática, 1994, p. 95-115.

FAORO, R. Machado de Assis: a pirâmide e o trapézio. Rio de Janeiro. Globo, 1988.

FAORO, R.A cidade convulsionada. Isto É, São Paulo, n. 213, p.13, 22 jan.1981.

FAORO, R. A guerra dos Orixás. Isto É, São Paulo, n.212, p.14, 14 jan.1981.

FAORO, R. O nordeste em questão: acertando as contas com a velha hegemonia. Isto É, São Paulo, n. 215, p.17, 4 fev.1981.

FAORO, R. O chefe e a sombra. Isto É, São Paulo, n. 216, p.17, 11 fev.1981.

FAORO, R. Nós, os suspeitos. Isto É, São Paulo, n. 217, p.21, 18 fev.1981.

FAORO, Raymundo (1981f) A insegurança como tutela. Isto É, São Paulo, n. 218, p. 17,25 fev. 1981 .

FAORO, R. Os resíduos da transição. Isto É, São Paulo, n.221, p.21, 18 mar. 1981.

FAORO, R. Só o futuro o dirá. Isto É, São Paulo, n.220, p.13, 11 mar.1981.

FAORO, R. Quem acredita na democracia. Isto É, São Paulo, n.230, p.15, 20 maio 1981.

FAORO, R. Uma ilusão trágica. CartaCapital, São Paulo,n.89, p.22, 23 dez.1998.

FURTADO, C. Os ares do mundo. In Obra autobiográfica. São Paulo, Paz e Terra, 1997, p. 41-390, Tomo III

FURTADO, C. Brasil, a construção interrompida. São Paulo, Paz e Terra, 1992. 
FURTADO, C. Confrontações ideológicas no Brasil. Folha de S. Paulo, São Paulo, 31 dez. 2002. C.A, p.3.

FIGUEIREDO, J. B. [Gal.] apud O PESO da segurança. Veja, São Paulo, n.523, p.21, 13 set. 1978 .

OLIVEIRA, E. R. Conflits militaires et décisions sous la Présidence du Général Geisel (1974-1979) In ROQUIÉ, A. Les partis militaire au Brésil. Paris: Presses de la Foundation Nacionale des Sciencie Politiques, 1980.

REZENDE, M. J. de. A interpretação de Raymundo Faoro acerca dos procedimentos não-democráticos do governo Collor: uma análise da transição política brasileira nos anos de 1991 e 1992. Iberoamericana, Berlim/Madrid, n. 23, p.35-54, 2006.

REZENDE, M. J. de. As reflexões de Raymundo Faoro sobre a transição política brasileira nos anos 1989 e 1990 . Política \& Sociedade. Florianópolis, v.5, n.09, p.91-121, 2006 ${ }^{\mathrm{a}}$.

REZENDE, M. J. de. O capitalismo brasileiro e as modernizações desvinculadas da modernidade. Ensaios FEE, Porto Alegre, v.27, n.1, p. 207233, $2006 \mathrm{~b}$.

REZENDE, M. J. de. Os estamentos e a política nacional. Sociologia, São Paulo: Escala, n.18, p.30-37, 2008.

REZENDE, M. J. de. O penúltimo ano do governo Sarney (1988) expondo o malogro da transição política brasileira: a análise de Raymundo Faoro. Ensaios FEE, Porto Alegre, v.29, n.1, p. 179-206, 2008 b.

REZENDE, M. J. de. Alguns embaraços do projeto de abertura política no Brasil que foram apontados por Raymundo Faoro em seus artigos publicados na grande imprensa entre maio e dezembro de 1980. In CHAIA, V. e MACHADO, E (orgs.) Ciências sociais na atualidade. São Paulo, Paulus, 2009. p.133-164.

REZENDE, M. J. de. A transição como forma de dominação política. Londrina, Eduel, 1996.

REZENDE, M. J. de. A ditadura militar no Brasil: repressão e pretensão de legitimidade. Londrina, Eduel, 2001. 
STEPAN, A. Os militares: da abertura à Nova República. Rio de Janeiro, Paz e Terra, 1986.

STEPAN, A. As prerrogativas militares nos regimes pós-autoritários: Brasil, Argentina, Uruguai e Espanha In Democratizando o Brasil. Rio de Janeiro: Paz e Terra, 1988, p. 521-562.

STEPAN, A. The military in politics: changing patterns in Brazil. Princeton, Princeton University, 1971.

ZAVERUCHA, J. Semidemocracia. Folha de S. Paulo, São Paulo, 26 nov.2004. CA, p.3.

ZAVERUCHA, J. Frágil democracia: Collor, Itamar, FHC e os militares (1990-1998). Rio de Janeiro, Civilização Brasileira, 2000.

ZAVERUCHA, J. Entrevista apud Especialista defende reforma de lei militar. Folha de S. Paulo, São Paulo, 22 mar.2009. CA, p.11. 